\title{
Crystallization history of the Argyle and Ellendale olivine lamproites: constraints from spinel-olivine thermometry and oxygen barometry
}

\author{
Taylor, W.R. ${ }^{1}$, and Jaques, A.L. ${ }^{2}$
}

${ }_{1}^{1}$ R.S.E.S., Australian National University, Canberra, A.C.T. 0200, Australia

${ }^{2}$ Australian Geological Survey Organisation, GPO Box 378, Canberra, A.C.T. 2601, Australia

New calibrations of the olivine-spinel oxygen sensor and Fe-Mg exchange thermometer, corrected for the effect of $\mathrm{Ti}$ (Taylor et al., 1998), have been applied to magmatic Ti-rich chromian spinels from the Ellendale and Argyle olivine lamproite pipes (Kimberley region, Western Australia) in order to place quantitative constraints on their crystallization histories. Previous investigations of magmatic spinels from various lamproites have shown that lamproitic magmas generally evolve from reduced $\mathrm{fO}_{2}$ conditions near or below the $\mathrm{MW}$ buffer towards more oxidized conditions at $\mathrm{fO}_{2}>\mathrm{FMQ}$ (e.g. Prairie Creek, S.E. Spain lamproites, Ellendale pipe 4; Mitchell and Bergman, 1991). However, in some cases, notably Argyle and the Metters Bore lamproite (Jaques et al., 1989; Hwang et al., 1994), there has been no significant late-stage oxidation and the magmas have remained reduced through their crystallization interval. No explanation for these differences has been proposed, in part, because detailed quantitative $\mathrm{T}-\mathrm{fO}_{2}$ data has been lacking. It has been speculated that the maintenance of low $\mathrm{fO}_{2}$ conditions during magmatic crystallization could favour preservation of diamonds and so affect diamond grade.

For this investigation over 200 WDS microprobe analyses of groundmass, and olivine- or phlogopite-included chromian spinels were undertaken. Samples included olivine lamproite from the magmatic cores of four Ellendale pipes (No.s 4, 7, 9 and 11) and tuffaceous lamproite and olivine-phlogopite lamproite (late-stage dykes) at Argyle. At Argyle, diamond grades vary from $>500 \mathrm{ct} / 100 t$ in the Sandy tuff to $\leq 100 \mathrm{ct} / 100 \mathrm{t}$ in the Non-Sandy tuff. The magmatic Ellendale lamproites are relatively diamond poor with average grades near $0.5 \mathrm{ct} / 100 \mathrm{t}$ for pipe No.s 4, 7, 11 and 0.4-2.3 ct/100t for the No.9 core.

Spinel compositions in the olivine lamproites range from titanian aluminous magnesiochromites (TMAC) with cr\# 70-90, mg\# >60 through titanian magnesiochromite (TMC) with cr\# $>90, \mathrm{mg} \# 30-60$ to titanian chromian magnetite (TCM) or titanomagnetite (as rims with up to $20 \mathrm{wt} \% \mathrm{TiO}_{2}$ ) in the most oxidized systems. Where possible coexisting olivine grains were analysed, and in cases where olivine could not be determined, this data provided sufficient coverage to enable estimation of olivine composition (mostly Fo 91.5 \pm 1.0 ). Temperatures calculated with the olivine-spinel thermometer range from $\approx 1200^{\circ} \mathrm{C}$ for near liquidus TMAC grains to $\approx 700^{\circ} \mathrm{C}$ for late-crystallizing TMC and TCM grains. These latter grains have presumably re-equilibrated to subsolidus conditions. Oxygen fugacity was calculated with the equations of Taylor et al (1998) using a silica activity value appropriate for lamproitic magmas (0.6 log units below the Fo-En silica buffer; cf. Mitchell and Bergman, 1991). The results shown in Figures 1 to 3 reveal several interesting features:

(1) Tuffaceous and late magmatic lamproites from Argyle (Fig. 1) have crystallized under relatively uniform, reduced $\mathrm{fO}_{2}$ conditions of IW+2 to IW+3 log units. There is no late-stage evolution to more oxidized conditions. The shape of the $\mathrm{T}-\mathrm{fO}_{2}$ curve suggests oxidation state control by internal buffering equilibria between silicate, oxide and melt phases.

(2) Ellendale-9 (Fig.2) and to a lesser extent Ellendale-4 and -11 olivine lamproites have evolved from reduced to more oxidized conditions. Spinels recording high temperature, near liquidus conditions are relatively uncommon compared to lower temperature spinels suggesting extensive re-equilibration during cooling. Magma ponding in large near-surface bodies followed by a protracted cooling period and perhaps ingress of meteoric fluids is most likely responsible for late oxidation in these lamproites.

(3) Ellendale-7 (Fig.3) shows a crystallization history similar to that of Argyle. The geometry of the Ellendale-7 magmatic core appears to be distinct from the other Ellendale pipes (Jaques et al., 1986) and no significant bodies of ponded magma may have been present. 
Fig.1 Argyle

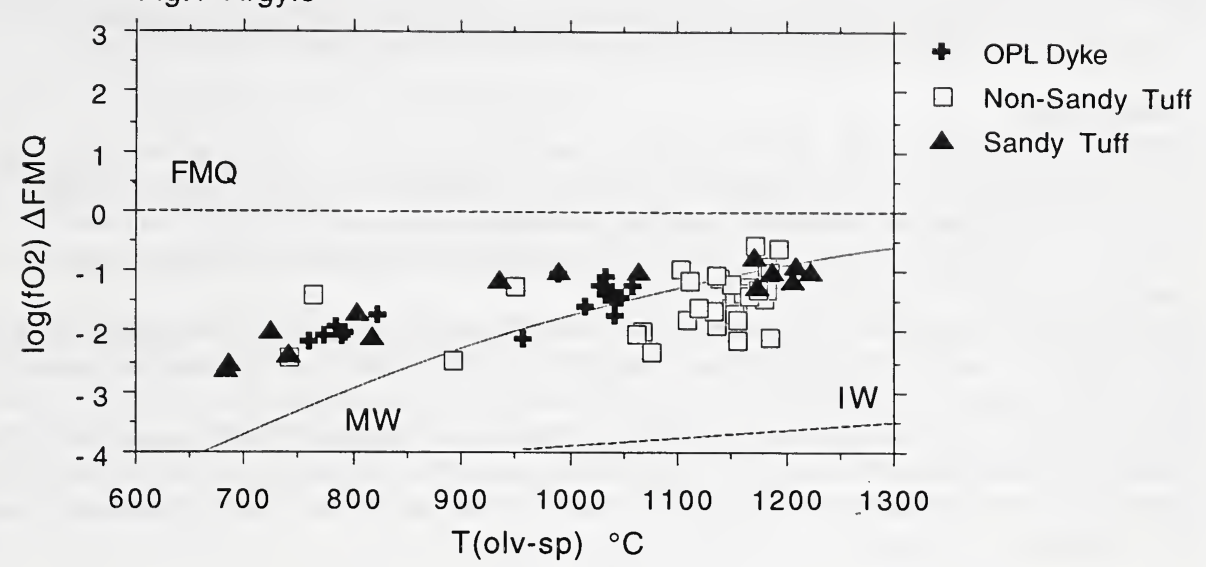

Fig.2 Ellendale-4 and Ellendale-9

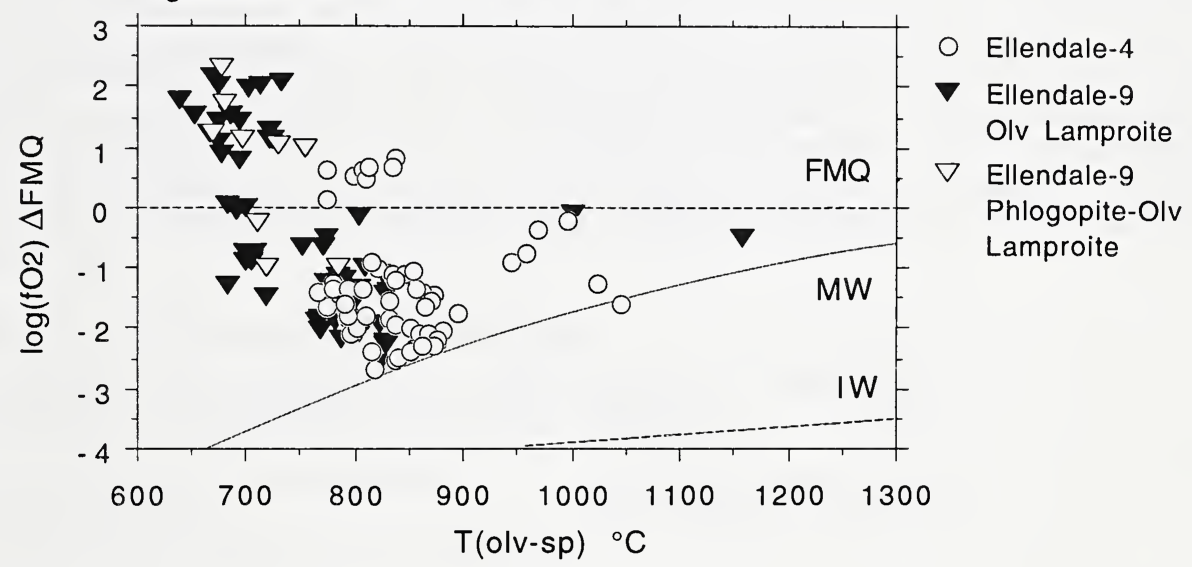

Fig.3 Ellendale-7 and Ellendale-11

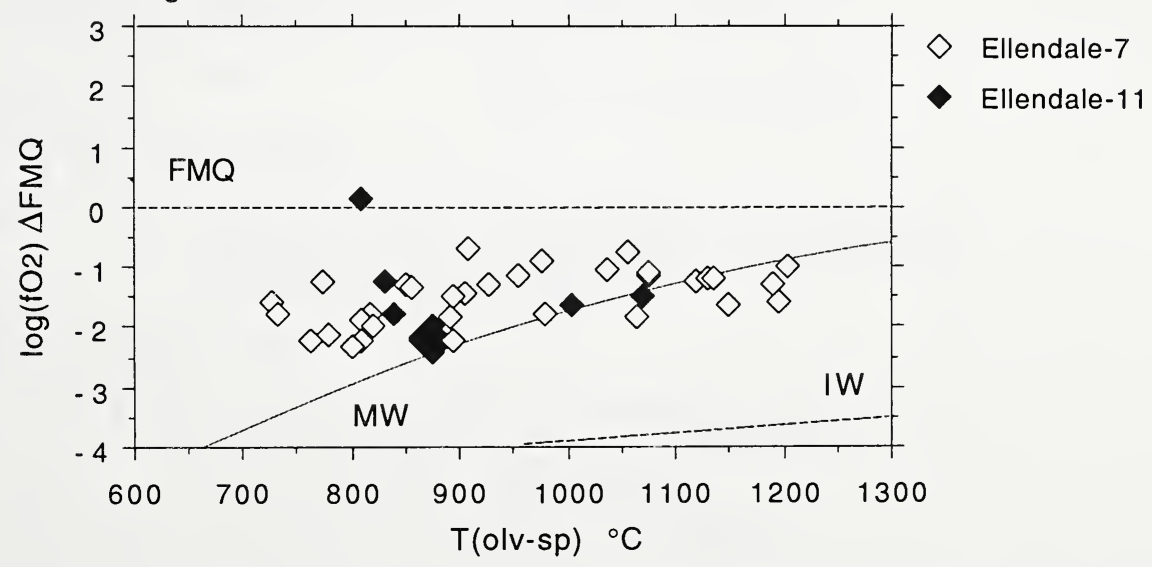

Figures 1-3

$\mathrm{Log}\left(\mathrm{fO}_{2}\right)$ vs $\mathrm{T}$ (olivine-spinel) diagrams (calculated for $\mathrm{P}=1 \mathrm{~atm}$ ) showing $\mathrm{T}-\mathrm{fO}_{2}$ evolution of the Argyle and Ellendale olivine lamproites relative to the FMQ reference buffer. Curves for the MW and IW reference buffers also shown. 
The results indicate that the primary magmatic oxidation state of the Ellendale and Argyle olivine lamproites is relatively reduced $(\mathrm{fO} 2 \sim \mathrm{IW}+2)$. There is no apparent evidence of a correlation between $\mathrm{T}-\mathrm{fO}_{2}$ history of the magma and measured diamond grade.

\section{References}

Hwang, P., Taylor, W.R., Rock, N.M.S., and Ramsay, R.R., 1994, Mineralogy, geochemistry and petrogenesis of the Metters Bore No.1 lamproite pipe, Calwynyardah field, West Kimberley province, Western Australia: Min. Petrol., 51, p. 195-226.

Jaques, A.L., Lewis, J.D., and Smith, C.B, 1986, The kimberlites and lamproites of Western Australia: Bull. 132, Geol. Sur. W. Aust.

Jaques, A.L., Haggerty, S.E., Lucas, H., and Boxer, G.L., 1989, Mineralogy and petrology of the Argyle (AK1) lamproite pipe, Western Australia: Kimberlites and related rocks, Vol. 1, Geol. Soc. Aust. Special Publ., 14, p. 153-169.

Mitchell, R.H., and Bergman, S.C., 1991, Petrology of lamproites: Plenum Press, New York.

Taylor, W.R., Kamperman, M., and Hamilton, R. (1998) New thermometer and oxygen fugacity sensor calibrations for ilmenite- and chromian spinel-bearing peridotitic assemblages: this volume. 